\title{
Examining the morphometric features of bulbus oculi in Van cats by using computed tomography and magnetic resonance imaging
}

\author{
Osman YILMAZ ${ }^{1, a, ~} \bowtie$, Fatma DURMAZ ${ }^{2, b}$ \\ ${ }^{1}$ Van Yüzüncü Y1l University, Faculty of Veterinary Medicine, Department of Anatomy, Van, Turkey; ${ }^{2}$ Van Yüzüncü Y1l University, \\ Faculty of Medicine, Department of Radiology, Van, Turkey. \\ aORCID: 0000-0003-2013-9213; bORCID: 0000-0003-3089-7165. \\ ${ }^{\square}$ Corresponding author: osman 40 5@hotmail.com \\ Received date: 25.08.2020 - Accepted date: 10.12.2020
}

\begin{abstract}
This study was conducted to obtain the morphometric and volumetric measurements of bulbus oculi of Van cats, growing around the city of Van in Turkey and named after here, by using computed tomography (CT) and magnetic resonance imaging (MRI), and to reveal the biometric differences of these measurement values between the sexes. A total of 16 adult Van cats including 8 females and 8 males were used in the study. The animals were anesthetized with the combination of xylazine and ketamine. The anesthetized animals were scanned by using CT and MRI devices and their images were obtained. Then, the morphometric and volumetric measurements of bulbus oculi were calculated from these images using the software (Syngo CT Software) in the workstation and their statistical analysis was performed. Upon the examination of the morphometric and volumetric analysis results, it was determined that while W (bodyweight) and ACL (Left Anterior Chamber) values were higher in male cats, DVLL (Dorsoventral length of the left lens) value was higher in female cats. These differences between the sexes were statistically significant $(\mathrm{P}<0.05)$. The volumetric measurement values of bulbus oculi and lens were determined to be averagely $4.60 \pm 0.27 \mathrm{~cm}^{3}$ and $0.67 \pm 0.09 \mathrm{~cm}^{3}$, respectively. In conclusion, the statistical differences of biometric values of bulbus oculi between male and female Van cats were determined by using CT and MRI. It is thought that the present study would contribute to the ophthalmological applications and the students receiving anatomy education.
\end{abstract}

Keywords: Bulbus oculi, computed tomography, magnetic resonance imaging, morphometry, Van cat.

\section{Van kedilerinde bulbus oculi’nin bilgisayarlı tomografi ve manyetik rezonans görüntüleme ile morfometrik özelliklerinin incelenmesi}

Özet: Bu çalışma, Türkiye'de Van ili yöresinde yetiştirilen ve ismini buradan alan Van kedilerinde bulbus oculi'nin bilgisayarlı tomografi (BT) ve manyetik rezonans görüntüleme (MRG) ile morfometrik ve volümetrik ölçülerini elde etmek ve bu ölçüm değerlerinin cinsiyetler arasındaki biyometrik farklılıklarını ortaya koymak amacıyla yapıldı. Çalışmada 8 dişi, 8 erkek olmak üzere toplam 16 adet erişkin Van Kedisi kullanıldı. Hayvanlar ketamin-ksilazin kombinasyonu ile anesteziye alındı. Anestezi altındaki hayvanlar BT ve MRG cihazı ile taranarak görüntüleri elde edildi. Daha sonra bu görüntülerden iş istasyonundaki yazılım programı (Syngo CT Software) kullanılarak bulbus oculi’nin morfometrik ve volümetrik ölçümleri hesaplandı ve istatistiki analizi yapıldı. Morfometrik ve volümetrik analiz sonuçlarına bakıldığında, W (vücut ağırlığı) ve ACL (sol ön kamera) değerlerinin erkek kedilerde; DVLL (sol lens'in dorsoventral uzunluğu) değerinin ise dişi kedilerde daha yüksek olduğu tespit edildi. Cinsiyetler arasındaki bu farkların istatistik olarak önemli düzeyde olduğu gözlendi $(\mathrm{P}<0,05)$. Bulbus oculi ve lens'e ait volümetrik ölçüm değerleri sırasıyla ortalama 4,60 $\pm 0,27 \mathrm{~cm}^{3}$ ve $0,67 \pm 0,09 \mathrm{~cm}^{3}$ olarak belirlendi. Sonuç olarak, Van kedilerinde bulbus oculi'nin biyometrik değerlerinin istatistiksel olarak erkek ve dişiler arasındaki farklılıkları BT ve MRG kullanılarak tespit edildi. Sunulan çalışmanın bu kedilerle ilgili oftalmatolojik uygulamalara ve anatomi eğitimi alan öğrencilere katkı sağlayacağı düşünülmektedir.

Anahtar sözcükler: Bilgisayarlı tomografi, bulbus oculi, manyetik rezonans görüntüleme, morfometri, Van kedisi.

\section{Introduction}

Van cats have attracted great interest in recent years due to its unique physical characteristics and especially being included in the endangered species. Being growing around the city of Van in Turkey and named after here,
Van cats are known for their eye colors (their eyes may be amber or blue or they have heterochromia), triangularshaped head, soft coat on their bodies, fluffy tail, love of swimming and grooming, intelligence, and superior 
learning ability. Van cats are an important source of the cultural wealth of the region (21).

The eye is a sense organ that can receive and process light stimuli from the surrounding environment and transmit them to the visual cortex of the central nervous system by converting them into an electrical signal by anatomic and physiological mechanisms (10). Being the organ of sight, the eye consists of bulbus oculi (the eyeball) and organa oculi accessoria (accessory organs of the eye). Bulbus oculi, which has an active role in sight, forms the optic structure of the eye. Bulbus oculi, which is situated in orbit, has a three-layered structure including tunica fibrosa bulbi (sclera and cornea), tunica vasculosa bulbi (choroidea, corpus ciliare, and iris), and tunica interna bulbi (retina) (9). Bulbus oculi varies among animal species and breeds in terms of shape and size. In general, when the domestic mammals are listed based on their body sizes, cats have the biggest bulbus oculi, which is followed by the dog, horse, cattle, and pig, respectively (18).

The technological advancements in the computeraided medical imaging fields such as computed tomography and magnetic resonance imaging as well as three-dimensional modeling and various software programs enable to determine of the features of many anatomic structures in human or animal bodies, and evaluation easily any pathological change in these structures (2, 39). These imaging methods provide a perfect morphological detail in imaging of the eye and relevant (peripheral) complex anatomic structures particularly in small pets such as cats and dogs $(7,22)$. Also, the ocular and periocular benign and malignant aggressive tumors, orbital neoplasia, various inflammation cases, cystic structures, traumas, fractures, and foreign bodies in the region can be identified easily by means of CT, MRI, and the three-dimensional reconstruction software. Briefly, they are commonly used in diagnosing eye and orbital diseases and evaluating the diagnosis and treatment activities in veterinary medicine (7, 38).

Various studies concerning the anatomic and morphometric features of bulbus oculi have been conducted on horses $(13,24)$, cattle $(13,27)$, pigs (13), camels (16), sheep $(8,11)$, goats $(23)$, various dog breeds $(4,25,30,37)$, and cats $(3,5,19)$ from domestic mammals. However, no study has been found on the bulbus oculi in Van cats in the literature reviews. This study was conducted to provide the imaging of anatomic structures of bulbus oculi of Van cats by using computed tomography and magnetic resonance imaging, obtain its morphometric and volumetric measurements, and reveal the biometric differences of these measurement values between the sexes.

\section{Materials and Methods}

Animal materials: In the study, a total of 16 adult Van cats (between 3 and 8 years old, the average bodyweight (W) $4.91 \mathrm{~kg}$ for males and $3.60 \mathrm{~kg}$ for females), eight females and eight males, were used. The cats were obtained from Van Yüzüncü Y1l University Van Cat Research and Application Center. Ad libitum cat feed and drinking water were provided to these cats until the day before the study. This study was approved by the Van Yüzüncü Yıl University Animal Experiments Local Ethics Committee.

Anesthesia: The cats included in the study were numbered, and were not provided any feed starting the day before the study. Then, the cats were anesthetized with xylazine (1 - $2 \mathrm{mg} / \mathrm{kg}$, IM, Alfazyne ${ }^{\circledR} 2 \%$ injectable) ketamine (15 mg / $\mathrm{kg}$, IM, Ketasol ${ }^{\circledR} 10 \%$ injectable) combination.

Imaging with computed tomography: For the computed tomography (CT) tests of the Van Cats, a 16section multi-sequential computed tomography (CT) device (Somatom Sensation 16; Siemens Medical Solutions, Erlangen, Germany) was used in the Department of Radiology of Medicine Faculty of Van Yüzüncü Yıl University. A disposable sheet was placed onto the gantry of the device, and the cats were laid onto this sheet head-first in a prone position to achieve symmetry. The device parameters for the CT scan were adjusted as follows: Section thickness, $0.5 \mathrm{~mm}$; physical detector collimation, $16 \times 0.6 \mathrm{~mm}$; feed/rotation, $6 \mathrm{~mm}$; kernel, U90u; final section collimation, $32 \times 0.63 \mathrm{~mm}$; $\mathrm{KV} /$ rotation time $(\mathrm{sec})$ values/effective mAs, 120 / $0.75 / 120$; gantry rotation period, $420 \mathrm{~ms}$; increment, 0.5 $\mathrm{mm}$; resolution, $512 \times 512$ pixels. Scanning and dosage parameters were performed in accordance with standard protocols found in published literature $(15,28)$. The images obtained were recorded in the DICOM format.

Magnetic resonance imaging (MRI): The Van cats being ready for the study were laid in prone position under anesthesia and they were scanned by MRI. The T1 weighted sagittal data obtained from the MRI device was used for image analysis. MRI parameters were adjusted as follows; the field of view of $16 \mathrm{~cm}$, the repetition time of 19.2 milliseconds, echo time of 9.5 milliseconds, flip angle of $30^{\circ}$, resolution of $512 \times 512$ pixels, the resolution range of $0.31 \times 0.31 \mathrm{~mm}^{2}$, and the section thickness of 1 $\mathrm{mm}$. The obtained axial images were transferred to the workstation (Leonardo, Siemens Medical Solutions, Erlangen, Germany) for processing in DICOM format.

Measurements: Then, using the software in the workstation (Syngo CT Software) on these obtained images, the morphometric measurements obtained from the axial, and coronal sections were obtained from CT measurements and the morphometric measurements obtained from sagittal sections were obtained from T1- 
weighted MRI images as they were more demonstrative. On the other hand, the volumetric measurements were obtained by sectioning both bulbus oculi and lens from the outer border in all sections respectively from anterior to posterior in axial CT sections, obtaining colored images by means of the special software and then calculating the common volumetric data of all the sections. Figure 1, 2, 3, and 4 shows the morphometric and volumetric measurement points of the bulbus oculi of Van cats. All measurements were made from the widest part of the bulbus oculi and lens. The morphometric and volumetric measurements of the points on the bulbus oculi were determined in Table 1.

Table 1. The measurement points of the bulbus oculi and the abbreviations.

\begin{tabular}{|c|c|}
\hline Abbreviation & Explanation \\
\hline ABR & Axial (anterior- posterior) length of the right bulbus oculi $(\mathrm{cm})$ \\
\hline $\mathrm{ABL}$ & Axial (anterior- posterior) length of the left bulbus oculi $(\mathrm{cm})$ \\
\hline MLBR & Mediolateral length of the right bulbus oculi $(\mathrm{cm})$ \\
\hline MLBL & Mediolateral length of the left bulbus oculi (cm) \\
\hline DVBR & Dorsoventral length of the right bulbus oculi $(\mathrm{cm})$ \\
\hline DVBL & Dorsoventral length of the left bulbus oculi (cm) \\
\hline ALR & Axial (anterior- posterior) length of the right lens $(\mathrm{cm})$ \\
\hline ALL & Axial (anterior- posterior) length of the left lens $(\mathrm{cm})$ \\
\hline MLLR & Mediolateral length of the right lens $(\mathrm{cm})$ \\
\hline MLLL & Mediolateral length of the left lens $(\mathrm{cm})$ \\
\hline DVLR & Dorsoventral length of the right lens $(\mathrm{cm})$ \\
\hline DVLL & Dorsoventral length of the left lens $(\mathrm{cm})$ \\
\hline $\mathrm{ACR}$ & $\begin{array}{l}\text { Right Anterior Chamber (Anterior-posterior distance of the anterior chamber, from the cornea to the rostral } \\
\text { border of the lens) }(\mathrm{cm})\end{array}$ \\
\hline ACL & $\begin{array}{l}\text { Left Anterior Chamber(Anterior-posterior distance of the anterior chamber, from the cornea to the rostral border } \\
\text { of the lens) }(\mathrm{cm})\end{array}$ \\
\hline PCR & $\begin{array}{l}\text { Right Posterior Chamber (Anterior-posterior distance of the posterior chamber, from the caudal aspect of the } \\
\text { lens to internal surface of the bulbus oculi of the posterior segment) }(\mathrm{cm})\end{array}$ \\
\hline PCL & $\begin{array}{l}\text { Left Posterior Chamber (Anterior-posterior distance of the posterior chamber, from the caudal aspect of the lens } \\
\text { to internal surface of the bulbus oculi of the posterior segment) }(\mathrm{cm})\end{array}$ \\
\hline VLR & Volumetric value of the right lens $\left(\mathrm{cm}^{3}\right)$ \\
\hline VLL & Volumetric value of the left lens $\left(\mathrm{cm}^{3}\right)$ \\
\hline VBR & Volumetric value of the right bulbus oculi $\left(\mathrm{cm}^{3}\right)$ \\
\hline VBL & Volumetric value of the left bulbus oculi $\left(\mathrm{cm}^{3}\right)$ \\
\hline
\end{tabular}

Figure 1. Measurement points of the bulbus oculi in Van cats (axial CT image). DVB: Dorsoventral length of the bulbus oculi; MLB: Mediolateral length of the bulbus oculi; DVL: Dorsoventral length of the lens; MLL: Mediolateral length of the lens.

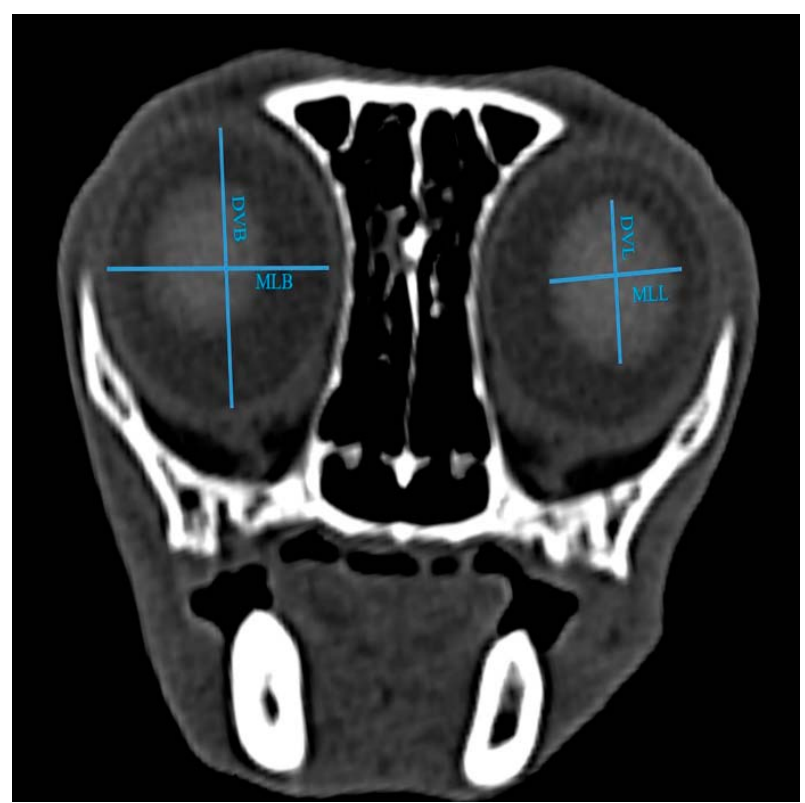


Figure 2. Measurement points of the bulbus oculi in Van cats (coronal CT image). AB: Axial (anterior - posterior) length of the bulbus oculi; AL: Axial (anterior - posterior) length of the lens.

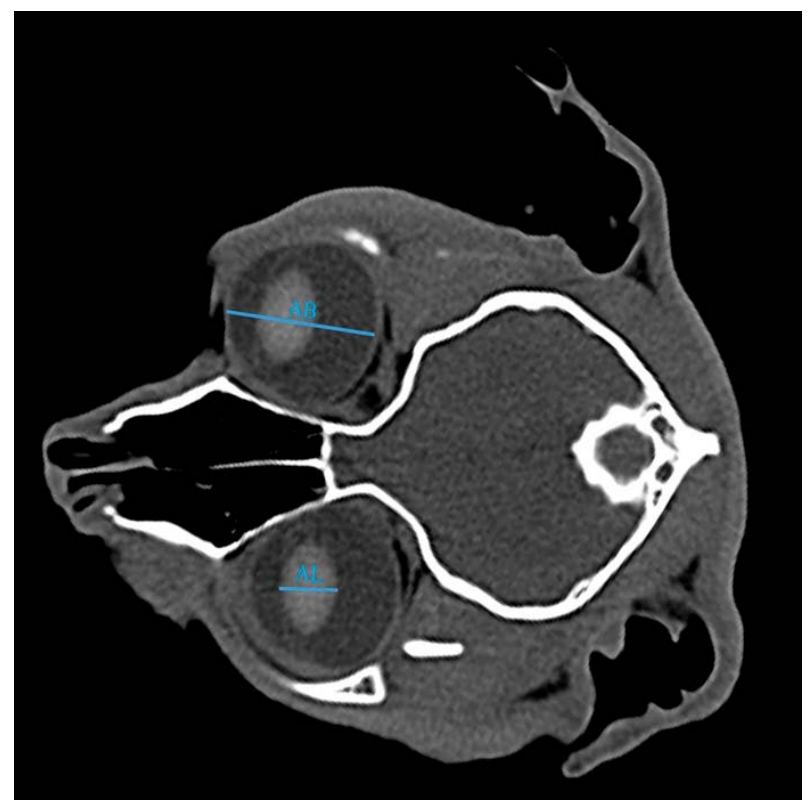

Figure 3. Measurement points of the bulbus oculi in Van cats (sagittal T1-weighted MRI image). AC: Anterior Chamber; PC: Posterior Chamber.
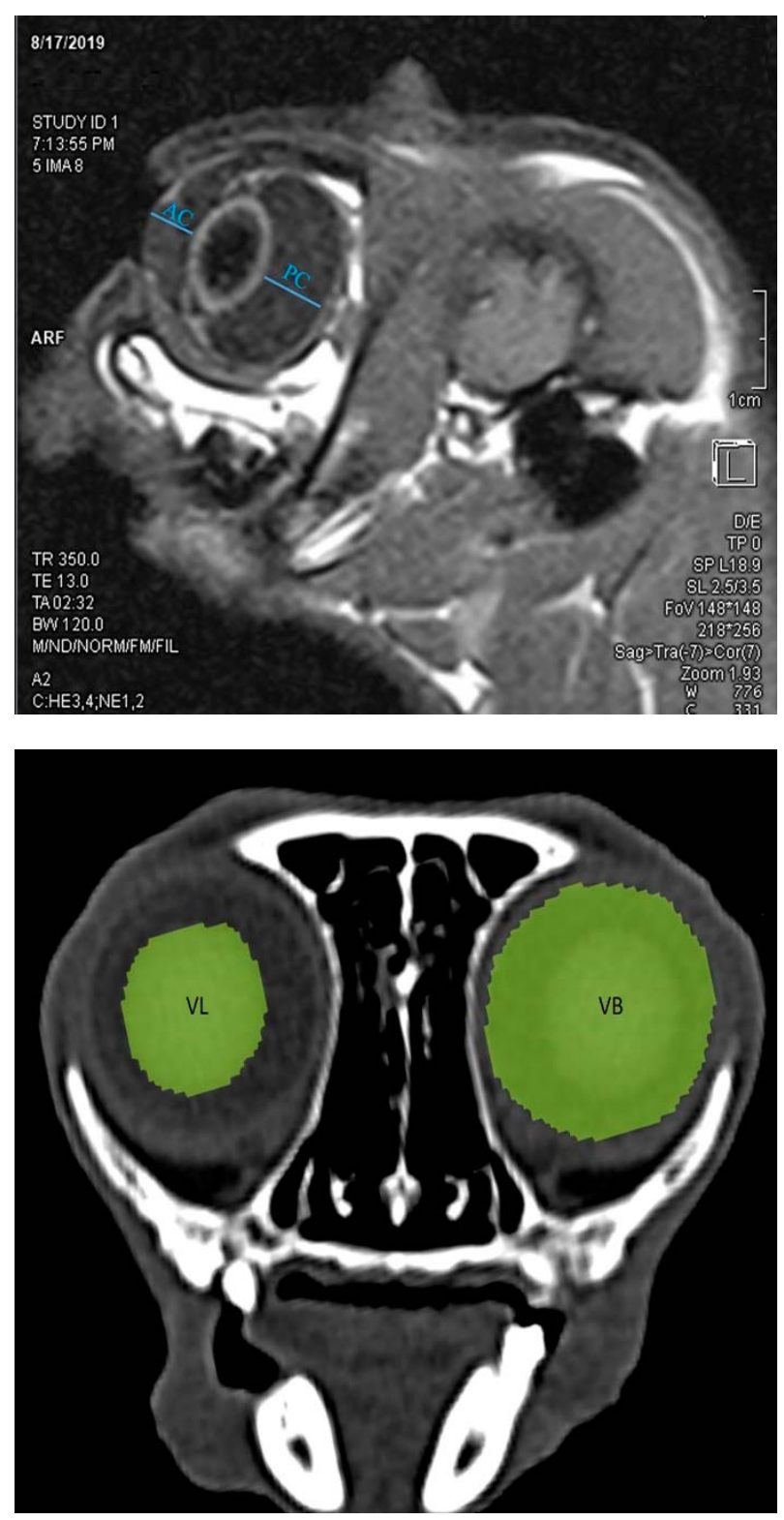

Figure 4. The process of calculating the volume value of the lens (VL) and the bulbus oculi (VB) in Van cats. 
Nomina Anatomica Veterinaria was used as terminology in the study (20). Digital scales $\left(\mathrm{TESS}^{\circledR}, \mathrm{RP}\right.$ - LCD) were also used for bodyweight (W) measurements.

Statistical analysis: Whether measurement averages in this study were normally distributed or not was controlled via the Shapiro-Wilk test $(n<50)$. Since it was found that measurements of the variables were not normally distributed, nonparametric tests were used. For the sample size in the study; G*Power statistics program (ver.3.1.9.4) was used. In the calculation, the power of the test was $95 \%$ and the type- 1 error was $5 \%$. Accordingly, it was appropriate to have a minimum of 8 cats in each group. Descriptive statistics for measurements in the study are communicated as mean, standard deviation, minimum, and maximum. Gender-related comparisons of the measurements were made through the Mann-Whitney U test. The correlation between measurements, excluding gender-related comparisons, was determined by Spearman correlation coefficients. In measurements, the level of statistical significance $(\alpha)$ was deemed to be $5 \%$. For all measurements, SPSS (IBM SPSS for Windows, Ver. 23) statistical package program was used.

\section{Results}

The morphometric and volumetric measurement values obtained from bulbus oculi by using CT and MRI were analyzed statistically in order to determine the differences between male and female groups in terms of continuous variables. Statistically significant differences between the measured values of the bulbus oculi were recorded $(\mathrm{P}<0.05)$. Tables 2-4 show the measured values.

Table 2. Morphometric and volumetric measurement values of the bulbus oculi according to gender.

\begin{tabular}{|c|c|c|c|c|c|c|c|c|}
\hline & Gender & $\mathbf{N}$ & Median & Mean & Std. Dev. & Min. & Max. & $* \mathbf{P}$ \\
\hline \multirow[t]{2}{*}{ A } & Male & 8 & 4.50 & 5.00 & 2.00 & 3.00 & 8.00 & 1.000 \\
\hline & Female & 8 & 4.50 & 5.00 & 2.00 & 3.00 & 8.00 & \\
\hline \multirow[t]{2}{*}{ W (kg) } & Male & 8 & 5.00 & 4.91 & 0.60 & 4.10 & 6.00 & 0.002 \\
\hline & Female & 8 & 3.40 & 3.60 & 0.48 & 3.10 & 4.30 & \\
\hline \multirow[t]{2}{*}{ VLR } & Male & 8 & 0.70 & 0.68 & 0.11 & 0.47 & 0.79 & 0.399 \\
\hline & Female & 8 & 0.64 & 0.65 & 0.08 & 0.52 & 0.76 & \\
\hline \multirow[t]{2}{*}{ VLL } & Male & 8 & 0.73 & 0.68 & 0.11 & 0.50 & 0.77 & 0.171 \\
\hline & Female & 8 & 0.63 & 0.62 & 0.09 & 0.44 & 0.71 & \\
\hline \multirow[t]{2}{*}{ ALR } & Male & 8 & 0.97 & 0.96 & 0.04 & 0.86 & 0.99 & 0.288 \\
\hline & Female & 8 & 0.95 & 0.94 & 0.05 & 0.83 & 0.99 & \\
\hline \multirow[t]{2}{*}{ MLLR } & Male & 8 & 1.12 & 1.12 & 0.05 & 1.05 & 1.20 & 0.833 \\
\hline & Female & 8 & 1.12 & 1.10 & 0.06 & 1.01 & 1.17 & \\
\hline \multirow[t]{2}{*}{ DVLR } & Male & 8 & 1.07 & 1.08 & 0.04 & 1.03 & 1.16 & 0.092 \\
\hline & Female & 8 & 1.14 & 1.15 & 0.09 & 0.99 & 1.27 & \\
\hline \multirow[t]{2}{*}{ ALL } & Male & 8 & 0.97 & 0.95 & 0.06 & 0.84 & 1.03 & 0.792 \\
\hline & Female & 8 & 0.96 & 0.94 & 0.05 & 0.85 & 0.99 & \\
\hline \multirow[t]{2}{*}{ MLLL } & Male & 8 & 1.10 & 1.11 & 0.04 & 1.05 & 1.18 & 0.596 \\
\hline & Female & 8 & 1.13 & 1.13 & 0.07 & 1.02 & 1.23 & \\
\hline \multirow[t]{2}{*}{ DVLL } & Male & 8 & 1.09 & 1.08 & 0.03 & 1.03 & 1.11 & 0.013 \\
\hline & Female & 8 & 1.13 & 1.15 & 0.08 & 1.00 & 1.28 & \\
\hline \multirow[t]{2}{*}{ VBR } & Male & 8 & 4.72 & 4.69 & 0.12 & 4.49 & 4.81 & 0.248 \\
\hline & Female & 8 & 4.52 & 4.57 & 0.43 & 4.07 & 5.44 & \\
\hline \multirow[t]{2}{*}{ VBL } & Male & 8 & 4.70 & 4.70 & 0.13 & 4.54 & 4.86 & 0.172 \\
\hline & Female & 8 & 4.46 & 4.53 & 0.40 & 4.16 & 5.34 & \\
\hline \multirow[t]{2}{*}{ ABR } & Male & 8 & 2.19 & 2.20 & 0.09 & 2.05 & 2.38 & 0.156 \\
\hline & Female & 8 & 2.15 & 2.14 & 0.08 & 2.00 & 2.23 & \\
\hline \multirow[t]{2}{*}{ MLBR } & Male & 8 & 2.11 & 2.08 & 0.08 & 1.93 & 2.16 & 0.102 \\
\hline & Female & 8 & 2.04 & 2.01 & 0.10 & 1.81 & 2.10 & \\
\hline \multirow[t]{2}{*}{ DVBR } & Male & 8 & 2.09 & 2.07 & 0.06 & 1.94 & 2.13 & 0.636 \\
\hline & Female & 8 & 2.09 & 2.07 & 0.11 & 1.86 & 2.21 & \\
\hline \multirow[t]{2}{*}{ ABL } & Male & 8 & 2.19 & 2.19 & 0.10 & 2.01 & 2.33 & 0.493 \\
\hline & Female & 8 & 2.16 & 2.16 & 0.08 & 2.05 & 2.28 & \\
\hline \multirow[t]{2}{*}{ MLBL } & Male & 8 & 2.07 & 2.06 & 0.07 & 1.97 & 2.14 & 0.429 \\
\hline & Female & 8 & 2.05 & 2.02 & 0.10 & 1.83 & 2.13 & \\
\hline \multirow[t]{2}{*}{ DVBL } & Male & 8 & 2.10 & 2.09 & 0.03 & 2.04 & 2.13 & 0.460 \\
\hline & Female & 8 & 2.07 & 2.05 & 0.09 & 1.88 & 2.13 & \\
\hline \multirow[t]{2}{*}{ ACL } & Male & 8 & 0.46 & 0.46 & 0.03 & 0.40 & 0.49 & 0.026 \\
\hline & Female & 8 & 0.41 & 0.42 & 0.02 & 0.39 & 0.46 & \\
\hline \multirow[t]{2}{*}{ ACR } & Male & 8 & 0.44 & 0.44 & 0.04 & 0.39 & 0.51 & 0.167 \\
\hline & Female & 8 & 0.42 & 0.42 & 0.03 & 0.39 & 0.48 & \\
\hline \multirow[t]{2}{*}{ PCL } & Male & 8 & 0.78 & 0.78 & 0.03 & 0.74 & 0.83 & 0.314 \\
\hline & Female & 8 & 0.79 & 0.80 & 0.03 & 0.78 & 0.86 & \\
\hline \multirow[t]{2}{*}{ PCR } & Male & 8 & 0.79 & 0.80 & 0.04 & 0.75 & 0.88 & 0.205 \\
\hline & Female & 8 & 0.77 & 0.77 & 0.04 & 0.71 & 0.84 & \\
\hline
\end{tabular}




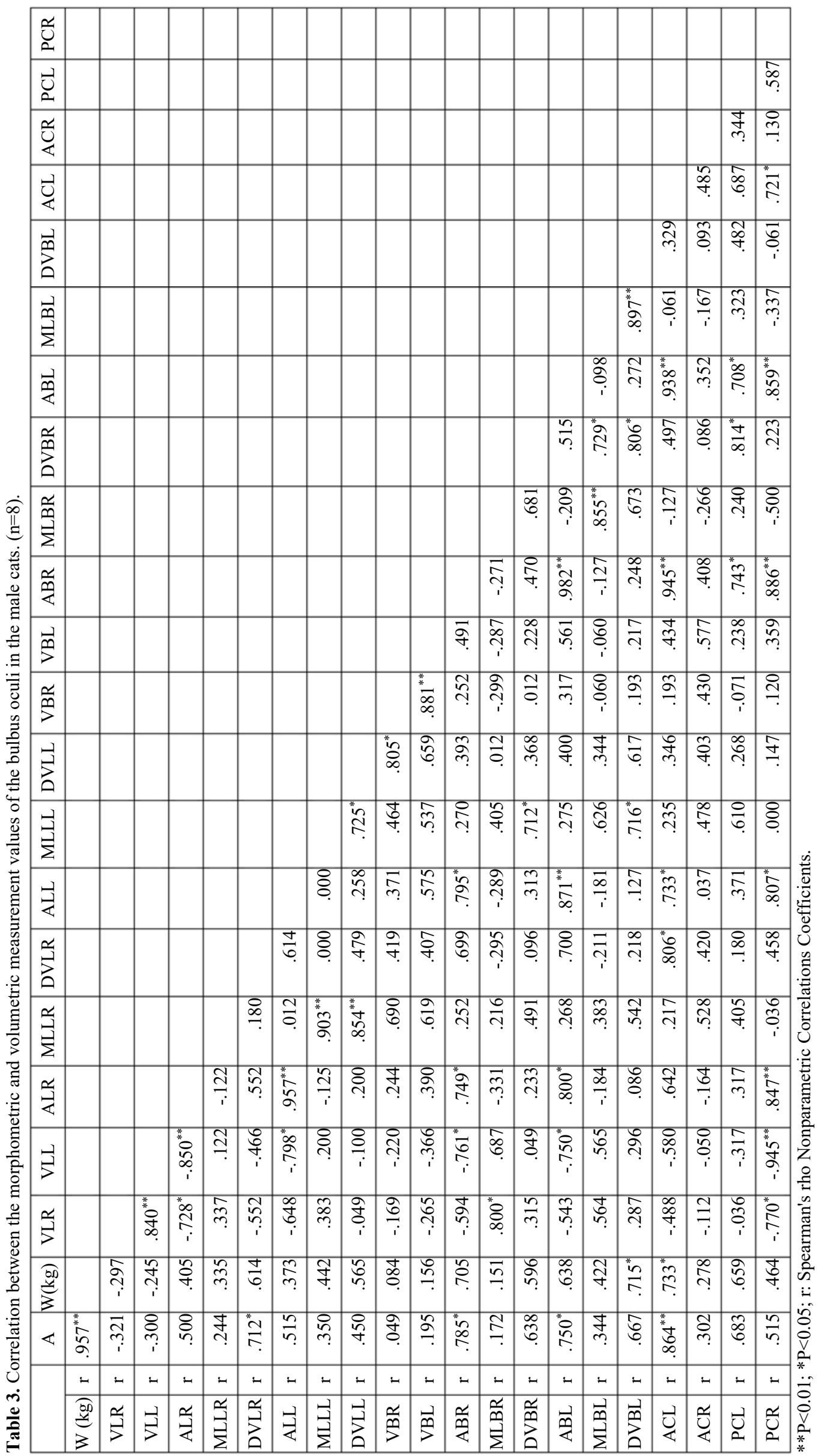




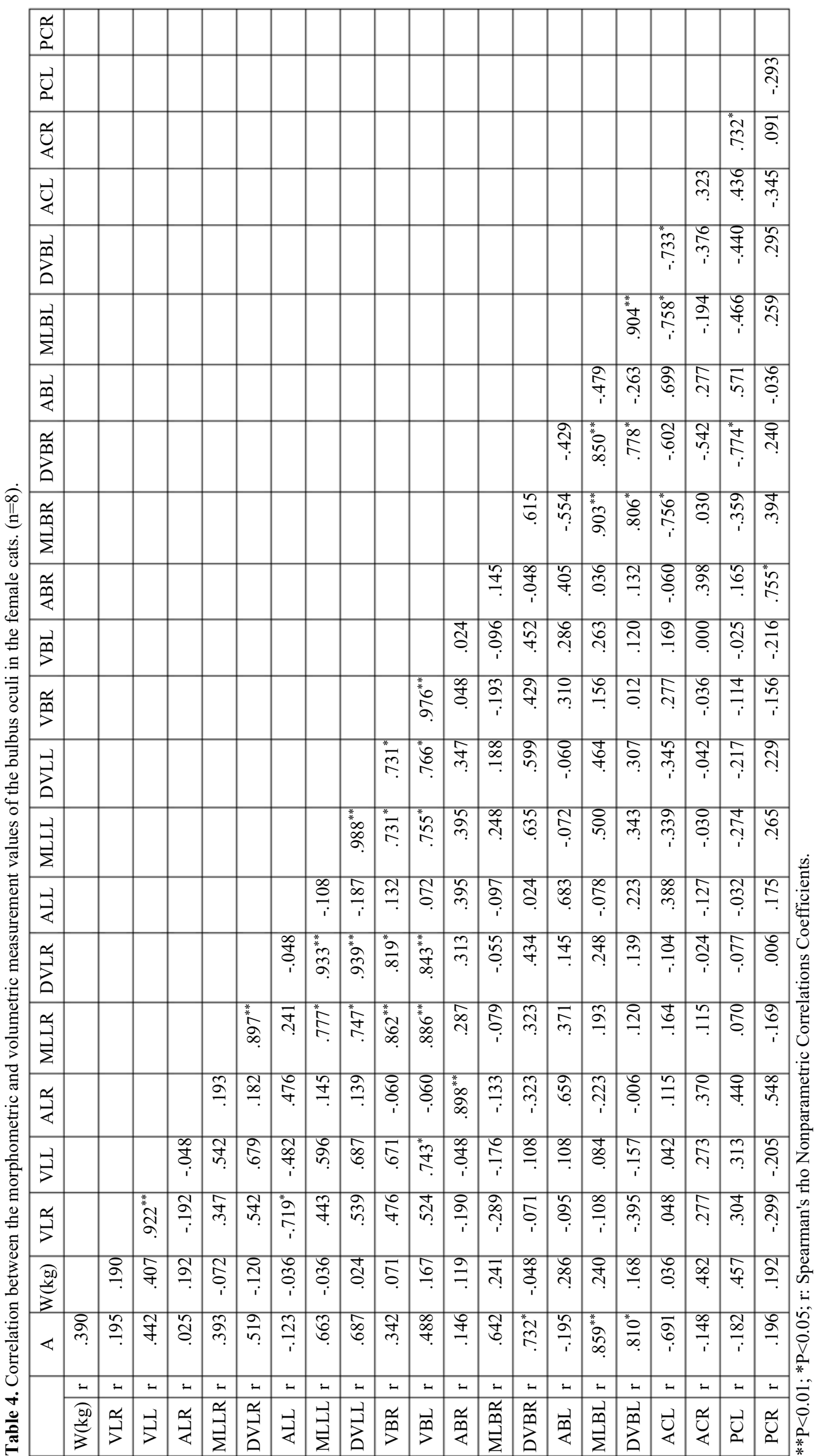


Table 2 shows morphometric and volumetric measurements of the bulbus oculi according to sex. Accordingly, it was determined that $\mathrm{W}$ and ACL values were higher in the male cats compared to the female cats. In addition, DVLL values were higher in the female cats compared to the male cats. These differences were statistically significant $(\mathrm{P}<0.05)$. No statistically significant difference was determined between the other average measurement values of bulbus oculi based on sex $(\mathrm{P}>0.05)$.

Table 3 shows the correlation between the morphometric and volumetric measurement values of bulbus oculi in the male cats. Accordingly, a positive significant correlation was determined between age with W, DVLR, ABR, ABL, and ACL measurement values, between bodyweight with DVBL and ACL measurement values; between VLR with VLL and MLBR measurement values; between ALR with ALL, ABR, ABL, and PCR measurement values; between MLLR with MLLL and DVLL measurement values; between DVLR with ACL measurement value; ALL with ABR, ABL, ACL, and PCR measurement values; between MLLL with DVLL, DVBR, and DVBL measurement values; between DVLL and VBR measurement value; between VBR and VBL measurement value; between ABR with ABL, ACL, PCR measurement values; between MLBR with MLBL measurement value; between DVBR with MLBL, DVBL, and PCL measurement values; between ABL with ACL, PCL, and PCR measurement values; between MLBL and DVBL measurement value; between ACL and PCL measurement value $(\mathrm{P}<0.05)$. On the other hand, there was a negative significant correlation between VLR with ALR and PCR measurement values; between VLL with ALR, ALL, ABR, ABL, and PCR measurement values $(\mathrm{P}<0.05)$.

Table 4 shows the correlation between the morphometric and volumetric measurement values of bulbus oculi in the female cats. Accordingly, a positive significant correlation was determined between age with DVBR, MLBL, and DVBL measurement values; between VLR and VLL measurement value; between VLL and VBL measurement value; between ALR and ABR measurement value; between MLLR with DVLR, MLLL, DVLL, VBR, and VBL measurement values; between DVLR with MLLL, DVLL, VBR, and VBL measurement values; between MLLL with DVLL, VBR, and VBL measurement values, between DVLL with VBR and VBL measurement values; between $\mathrm{VBR}$ and VBL measurement value; between ABR and PCR measurement value; between MLBR with MLBL, DVBL, and ACL measurement values; between DVBR with MLBL and DVBL measurement values; between MLBL and DVBL measurement value; and between ACR and PCL measurement value $(\mathrm{P}<0.05)$. However, a negative significant correlation was determined between VLR and
ALL measurement value; between DVBR and PCL measurement value; between ACL with MLBL and DVBL measurement values $(\mathrm{P}<0.05)$.

\section{Discussion and Conclusion}

The medical imaging methods such as A-mode Ultrasonography, B-mode Ultrasonography, Computed tomography, and magnetic resonance imaging are commonly used in imaging eye and the relevant complex anatomic structures, obtaining morphometric and volumetric measurement values from these images, and interpreting pathological conditions $(19,30,31,36)$. This study is the first attempt to determine the morphometric and volumetric values of the right-left bulbus oculi using CT and MRI in Van cats and reveal the biometric differences of these values between males and females.

No statistically significant differences were observed in the ocular biometric measurement values obtained from the various planes of the right and left eyes of some animals such as domestic cats (36), Persian cat (19), mesocephalic and dolichocephalic dogs (6), Saanen goats (29), Guinea pigs (40), rabbits (34), and Striped Owls (32). In this study, it was observed that ACL measurement values were higher in the male cats compared to the female cats. In addition, DVLL measurement values were higher in the female cats compared to the male cats. These differences were statistically significant $(\mathrm{P}<0.05)$. No statistically significant difference was determined between the other mean measurement values of the right and left bulbus oculi based on sex $(\mathrm{P}>0.05)$. It was observed that other findings of bulbus oculi other than ACL and DVLL measurement values were compatible with the literature data. In addition, in the study by Schiffer et al. (31), no statistical difference was found between the right and left axial bulbus oculi length measurement values and they reported based on the differences between sexes that this measurement value was significantly longer in male dogs compared to female dogs.

Gilger et al. (12), determined that the mean values of axial bulbus oculi length, anterior chamber depth, and axial lens thickness were $20.91 \pm 0.53 \mathrm{~mm}, 5.07 \pm 0.36$ $\mathrm{mm}$, and $7.77 \pm 0.23 \mathrm{~mm}$, respectively, in the ocular biometric measurements performed in 20 mixed-breed cats with clinically normal characteristics. Vosough et al. (36), determined that the mean values of axial bulbus oculi length, anterior chamber depth, axial lens thickness, and posterior chamber depth of the right and left eyes were approximately $17.1 \pm 0.1 \mathrm{~mm}, 3.9 \pm 0.1 \mathrm{~mm}, 5.0 \pm 0.1$ $\mathrm{mm}$, and $7.0 \pm 0.1 \mathrm{~mm}$, respectively, in the ocular morphometric examinations performed with 6 healthy female domestic shorthair cats. Mirshahi et al. (19), determined that these values were $20.7 \pm 1.0 \mathrm{~mm}, 4.1 \pm$ $0.7 \mathrm{~mm}, 7.7 \pm 0.5 \mathrm{~mm}$, and $8.2 \pm 0.4 \mathrm{~mm}$, respectively, in 
the ocular morphometric examinations of 40 healthy Persian cats. In this study, it was observed that these values were approximately $21.7 \pm 0.1 \mathrm{~mm}, 4.3 \pm 0.03 \mathrm{~mm}$, $9.6 \pm 0.8 \mathrm{~mm}$, and $7.8 \pm 0.3 \mathrm{~mm}$, respectively. It was considered that these differences observed between the morphometric measurement results of the mean values of axial bulbus oculi length, anterior chamber depth, axial lens thickness, and posterior chamber depth were due to the age, length, and breed characteristics of cats.

The studies have revealed that there is a correlation between body length and ocular size in humans (26) and dogs (6). However, in the present study, the ocular morphometric characteristics were assessed with bodyweight rather than body length. Accordingly, a positive, statistical correlation was determined between bodyweight and DVBL and ACL measurement values in male cats. Also, no significant correlation was observed between the ocular parameters and bodyweight in females. However, Hollis et al. (13), reported that there was a positive correlation between bodyweight and all the ocular structures except for lens and anterior chamber depth in horses.

In the study by Larsen (17), it was stated that the size of the eye developed and increased approximately until the age of 13 in humans. Also, Ribeiro et al. (29), reported that all the ocular parameters increased until the age of 549 days in Saanen goats. In the study conducted by Tuntivanich et al. (35), during the postnatal development period of dogs by using ultrasound they determined that the axial bulbus oculi increased until the $52^{\text {nd }}$ week. In the study conducted by Mirshahi et al (19), with Persian cats, they determined that there was a positive correlation between age and posterior chamber depth. In the present study, a positive significant correlation was determined between age and W, DVLR, ABR, ABL, and ACL measurement values in the male cats and between age and DVBR, MLBL, and DVBL measurement values in the female cats. Also, Tables 3 and 4 show the correlation between the other measurement values of ocular structures in male and female Van cats.

Eye volume is quite important in terms of some ocular diseases such as microphthalmus, buphthalmus (congenital glaucoma), and macrophthalmus (1). Especially in pets such as cats and dogs, eye volume can be calculated using various software developed from CT and MRI images $(1,3,14,30)$. In this study, the volumetric measurement values of bulbus oculi and lens in healthy Van cats were determined to be averagely 4.60 $\pm 0.27 \mathrm{~cm}^{3}$ and $0.67 \pm 0.09 \mathrm{~cm}^{3}$, respectively.

Using computed tomography and magnetic resonance imaging, the images with the appropriate thickness of the relevant anatomic structure can be obtained without giving any bodily harm to animals under anesthesia (33, 39). Additionally, imaging various anatomic structures morphologically, interpreting them and the morphometric and volumetric measurements of these anatomic structures can be easily performed (7, 22, 38). Due to these properties, these imaging methods are increasingly and commonly used in the field of veterinary anatomy recently together with the computer-aided technological developments $(2,39)$.

Consequently, the statistical differences between the male and female Van cats in terms of bulbus oculi biometric values were determined using CT and MRI. It is predicted that this study would guide the ophthalmological applications related to Van cats and the students receiving anatomy education. Also, it is thought that this study would significantly contribute to the scientific studies about the eye in Van cats.

\section{Financial Support}

This research received no grant from any funding agency/sector.

\section{Ethical Statement}

This study was approved by Van Yüzüncü Y1l University Animal Experiments Local Ethics Committee (the decision no: 2020 / 02 and date: 27. 02. 2020).

\section{Conflict of Interest}

The authors declared that there is no conflict of interest.

\section{References}

1. Acer N, Sahin B, Ucar T, et al (2009): Unbiased estimation of the eyeball volume using the Cavalieri principle on computed tomography images. J Craniofac Surg, 20, 233-237.

2. Brenton H, Hernandez J, Bello F, et al (2007): Using multimedia and web $3 D$ to enhance anatomy teaching. Comput Educ, 49, 32-53.

3. Chandrakumar SS, Zur Linden A, Owen M, et al (2019): Computed tomography measurements of intraocular structures of the feline eye. Vet Rec, 184, 651.

4. Chiwitt CHL, Baines SJ, Mahoney P, et al (2017): Ocular biometry by computed tomography in different dog breeds. Vet Ophthalmol, 20, 411-419.

5. Collins SP, Matheson JS, Hamor RE, et al (2013): Comparison of the diagnostic quality of computed tomography images of normal ocular and orbital structures acquired with and without the use of general anesthesia in the cat. Vet Ophthalmol, 16, 352-358.

6. Cottrill NB, Banks WJ, Pechman RD (1989): Ultrasonographic and biometric evaluation of the eye and orbit of dogs. Am J Vet Res, 50, 898-903.

7. Daniel GB, Mitchell SK (1999): The eye and orbit. Clin Tech Small Anim Pract, 14, 160-169.

8. Demircioğlu İ, Yılmaz B (2019): İvesi koyunlarında (Ovis aries) bulbus oculi'nin morfometrik yapısinin incelenmesi. Dicle Üniv Vet Fak Derg, 12, 108-111. 
9. Dursun N (2008): Veterinary Anatomy III. Medisan Publisher, Ankara, Turkey.

10. Dyce KM, Sack WO, Wensing CJG (2010): Textbook of Veterinary Anatomy. 332-345. 4th Edition, Saunders Elsevier Inc, Missouri, United States.

11. Fornazari GA, Montiani-Ferreira F, de Barros Filho IR, et al (2016): The eye of the Barbary Sheep or Aoudad (Ammotragus lervia): Reference values for selected ophthalmic diagnostic tests, morphologic and biometric observations. Open Vet J, 6, 102-113.

12. Gilger BC, Davidson MG, Howard PB (1998): Keratometry, ultrasonic biometry, and prediction of intraocular lens power in the feline eye. Am J Vet Res, 59, 131-134.

13. Hollis AR, Dixon JJ, Berlato D, et al (2019): Computed tomographic dimensions of the normal adult equine eye. Vet Ophthalmol, 22, 651-659.

14. Igbinedion BO, Ogbeide OU (2013): Measurement of normal ocular volume by the use of computed tomography. Niger J Clin Pract, 16, 315-319.

15. Kalra MK, Maher MM, Toth TL, et al (2004): Strategies for CT radiation dose optimization. Radiology, 230, 619628.

16. Kassab A (2012): Ultrasonographic and macroscopic anatomy of the enucleated eyes of the Buffalo (Bos bubalis) and the One-Humped Camel (Camelus dromedarius) of different ages. Anat Histol Embryol, 41, 7-11.

17. Larsen JS (1971): The sagittal growth of the eye. II: ultrasonic measurement of the axial diameter of the lens and the anterior segment from birth to puberty. Acta Ophthalmol, 49, 427-440.

18. Liebich HG, König HE (2007): Eye (organum visus). 571591. In: HE König, HG Liebich (Ed), Veterinary Anatomy of Domestic Mammals: Text Book and Colour Atlas. 3rd Edition, Schattauer, Germany.

19. Mirshahi A, Shafigh SH, Azizzadeh M (2014): Ultrasonographic biometry of the normal eye of the Persian cat. Aust Vet J, 92, 246-249.

20. Nomina Anatomica Veterinaria (2017): Prepared by the international committees on veterinary gross anatomical nomenclature and authorized by the general assembly of the world association of veterinary anatomists (6th Edition). The Editorial Committee Hanover (Germany), Ghent (Belgium), Columbia, MO (U.S.A.), Rio de Janeiro (Brazil).

21. Odabasioglu F, Ates CT (2000): Van Cats. 1st Edition, Selcuk University Printing Office, Konya, Turkey.

22. Ohlerth S, Scharf G (2007): Computed tomography in small animals-basic principles and state of the art applications. Vet J, 173, 254-71.

23. Olopade JO, Kwari HD, Agbashe IO, et al (2005): Morphometric study of the eyeball of three breeds of goats in Nigeria. Int J Morphol, 23, 377-380.

24. Patruno M, Perazzi A, Martinello T, et al (2017): Morphological description of limbal epithelium: searchingfor stem cells crypts in the dog, cat, pig, cow, sheep and horse. Vet Res Commun, 41, 169-173.

25. Paunksnis A, Svaldenienè E, Paunksnienė M, et al (2001): Ultrasonographic evaluation of the eye parameters in dogs of different age. Ultragarsas, 9, 48-51.

26. Pereira GC, Allemann N (2007): Ocular biometry, refractive error and correlation with height, age, gender and years of formal education. Arq Bras Oftalmol, 70, 487493.

27. Potter JT, Hallowell DG, Bowen IM (2008): Ultrasonographic anatomy of the bovine eye. Vet Radiol Ultrasound, 49, 172-175.

28. Prokop M (2003): General principles of MDCT. Eur J Radiol, 45, S4-S10.

29. Ribeiro AP, Silva ML, Rosa JP, et al (2009): Ultrasonographic and echobiometric findings in the eyes of Saanen goats of different ages. Vet Ophthalmol, 12, 313317.

30. Salgüero R, Johnson V, Williams D, et al (2015): $C T$ dimensions, volumes and densities of normal canine eyes. Vet Rec, 176, 386.

31. Schiffer SP, Rantanen NW, Leary GA, et al (1982): Biometric study of the canine eye, using A-mode ultrasonography. Am J Vet Res, 43, 826-830.

32. Squarzoni R, Perlmann E, Antunes A, et al (2010): Ultrasonographic aspects and biometry of Striped owl's eyes (Rhinoptynx clamator). Vet Ophthalmol, 13, 86-90.

33. Thrall DE (2007): Principles of computed tomography and magnetic resonance imaging. 20-77. In: Textbook of Veterinary Diagnostic Radiology. 5th Edition, Saunders Elsevier, St. Louis.

34. Toni MC, Meirelles AÉ, Gava FN, et al (2010): Rabbits'eye globe sonographic biometry. Vet Ophthalmol, 13, 384-386.

35. Tuntivanich N, Petersen-Jones SM, Steibel JP, et al (2007): Postnatal development of canine axial globe length measured by B-scan ultrasonography. Vet Ophthalmol, 10, $2-5$.

36. Vosough D, Shojaei B, Molazem M (2009): Magnetic resonance imaging of feline eye. Iran J Vet Res, 10, 66-69.

37. Williams DL (2004): Lens morphometry determined by $B$ mode ultrasonography of the normal and cataractous canine lens. Vet Ophthalmol, 7, 91-95.

38. Wisner ER, Zwingenberger AL (2015): Atlas of Small Animal CT and MRI: Orbit. 69-85. Willey-Blackwell Publishing, USA.

39. Yilmaz O, Soyguder Z, Yavuz A, et al (2020): Threedimensional computed tomographic examination of pelvic cavity in Van Cats and its morphometric investigation. Anat Histol Embryol, 49, 60-66.

40. Zhou X, Qu J, Xie R, et al (2006): Normal development of refractive state and ocular dimensions in guinea pigs. Vision Res, 46, 2815-2823. 